\title{
Teaching ESP at the Tertiary Level in Bangladesh: A General Perspective
}

\author{
Sharmin Siddique
}

\begin{abstract}
English is a foreign language in Bangladesh, and the tertiary students of private universities of different departments come with different vocational needs. General English courses cannot cater to the specific needs of the students of different departments. Moreover, at a tertiary level, English language courses should be designed not only to help students receive good grades, but also cater to their future workplace needs. In these cases, English for Specific Purposes (ESP) is more applicable than General English language courses. On the other hand, teaching ESP courses is more challenging and difficult than teaching General English courses. The article aims to characterize ESP, analysing its need in Bangladesh and identifying teachers' roles in its teaching. A survey was conducted for data collection in which two different sets of questionnaires were used for teachers and students. Twenty English language teachers and 64 undergrad students from the Department of Civil Engineering from different universities participated in the survey. Results of the survey have been presented with some recommendations for its pedagogic management.
\end{abstract}

Keywords: English for Specific Purpose, Tertiary level, Role of teachers, Needs analysis

\section{Introduction}

In Bangladesh, all private universities at the tertiary level offer some language courses (credit, as well as non-credit, which include Basic English or English Fundamentals, English Composition, Public Speaking, Technical Writing and Communication, Advanced Reading Strategies and Writing). These language courses, in theory, are designed according to the demand of the students of different departments so that the students not only pass exams and receive good grades, but also obtain professional development at work, for language learning is not only having knowledge of a language but also knowing how to function using it in the real world. Although all private Universities in Bangladesh offer mandatory English language courses, after completing these courses very few students achieve enough 
proficiency and accuracy in English to apply it in the job market. In this regard, Long (2005) states:

General (language for no purpose) courses at any proficiency level almost always teach too much, e.g., vocabulary, skills, registers or styles some learners do not need, and too little, e.g., omitting lexis and genres that they do. Instead of one-size-fits all approach, it is more defensible to view every courses as involving specific purposes (p. 19).

As English is a foreign language in Bangladesh, tertiary-level students come to private universities not only from different levels of language competence but also with different needs. For example, the skills that a Microbiology student needs varies from the needs of a Business Administration student. Thus, General English courses cannot cater to the language needs of the specific students (Huq, 2011). Furthermore, a foreign language learner would feel more confident if he/she knew the appropriate vocabulary related to a particular job. In this regard, ESP is more applicable than General English courses to the vocational needs of non-departmental students.

The article discusses some of the pertinent features of ESP, analyses its needs for Bangladeshi tertiary students and, based on the survey results, suggests ways to meet and for teachers to cater to students' needs.

\section{What is ESP?}

ESP is not a product but an approach to language learning where the content and the method are based on the learners' particular needs to learn the language (Hutchinson and Waters, 2002). In ESP, the purpose of learning the language is principal, and it is directly related to the vocational needs of the learners. Harding (2007) defines ESP as:

$$
\begin{aligned}
& \text { Whereas 'General English' is } \\
& \text { sometimes, perhaps unfairly, labeled } \\
& \text { English for no obvious purpose, in } \\
& \text { ESP- English for Specific Purposes- } \\
& \text { the purpose for learning the language } \\
& \text { is paramount and relates directly to } \\
& \text { what the learner needs to do in their } \\
& \text { vocation or job (p. 6). }
\end{aligned}
$$

In all definitions of ESP, two elements are obvious: the sense of purpose and the sense of vocation (Harding, 2007). Coffey (1984) discerns that ESP is a rapid and costeffective use of the English language to carry on a course of academic study (EAP) (Coffey, 1984). Lorenzo (2005, p.1) states that ESP "concentrates more on language in context than on teaching grammar and language structures."

Dudley- Evans and John (1998) describe some absolute and some variable characteristics to define ESP. According to them, ESP has the following absolute characteristics:

- $\quad$ ESP is intended to meet specific needs of the learners.

- ESP uses the fundamental methodology and activities of the disciplines that it serves.

- ESP is focused on the language suitable to the activities in terms of grammar, lexis, register, study skill, discourse and genre.

Similarly, variable characteristics include: 
- ESP may be linked to or planned for specific disciplines.

- $\quad$ ESP may use a changed methodology from General English.

- ESP is estimated to be designed for adult learners. It may be designed for secondary school level learners.

- Usually, ESP is designed for the intermediate or advanced students.

- Some basic knowledge of the language systems is expected in most ESP courses.

The term ESP emerged in 1960's as general English language courses could not meet the needs of the learners. After the end of Second World War in 1945, English was accepted as an international language. The rise of the United States as a superpower in technology and commerce, the revolution in linguistics (shifting attention away from defining the formal features of language usage to the ways in which language is used in real life), and the shifted focus to learners were identified as the three main reasons for the emergence of ESP (Hutchinson \& Waters, 2002). Nowadays, in EFL countries, the demand for ESP is growing rapidly for the following reasons. First, vocational learning and training throughout the world is increasing as education turns into less academic and more practical- and application- oriented. Second, spreading globalization, which includes politicians, business leaders, academic professors, hotel receptionists, nurses and site forepeople, has chosen English as the language of international communication. . Third, throughout the world, primary education covers the General English syllabus; thus, students do not wish to repeat the same coursework at secondary and tertiary levels. (Harding, 2012, p. 7)

In this regard Burton (2009) states:

ESP is not a monolithic universal phenomenon. Rather, it has developed at different speeds in different countries of the world and all the phases of development can be found functioning somewhere in the world at the present time. It could be said that ESP has increased over the decades as a result of market forces and a greater awareness amongst the academic and business community that learners' needs and wants should be met wherever possible ( $\mathrm{p}$. 12).

Because of the increasing needs of ESP in Bangladesh, most national and international companies, banks, nongovernment organizations, and software companies are arranging in-house language training programs. These companies focus on their immediate language needs. In Bangladesh, ESP training is not only limited to Business English, but also established in the fields of science and technology, aviation, marine navigation, medical professionals, etc. (Huq, 2011, p. 269)

\section{Needs Analysis and Target Situation Analysis}

Needs analysis is an essential and fundamental part of ESP, and has come through many stages. In Munby's Communicative Syllabus design in 1978, situations and functions were the framework of needs analysis where communicative needs were the basis for needs analysis. Based on the work of Munby, we also became familiarized with the term Target Situation Analysis (Songhori, 2008). 
Hutchinson and Waters (2002) distinguish between target needs and learning needs. First of all, the instructors have to make a basic distinction between the target needs (what the learners need to do in the target situation) and the learning needs (what the learners need to do to learn). They also classify target needs into necessities, lacks and wants. Necessities are the skills that the learners think they want to improve. Lacks have been defined as the gap between the target proficiency and the existing proficiency in English. Wants are individual lacks of the learners in the target language. They also provide the framework of needs analysis which is called Target Situation Analysis (TSA).

To analyze the target needs the following checklist can be used:

- Why is the language needed?

- How will the language be used?

- What will the content areas be?

- Who will the learners use the language with?

- When/Where will the language be used?

Similarly, to understand the learning needs, the following checklist can be used:

- Why are the learners taking the course?

- How do the learners learn?

- What resources are available?

- Who are the learners?

- When/Where will the course take place?

\section{Munby's Communicative Needs Processor}

Communicative Need Processor (CNP) (Munby 1978) is a set of need exploring procedures, which according to Waters (2002), provided a turning point in the development of ESP. The CNP, as a framework, enables teachers and/or course designers in identifying needs of a particular group or groups of learners.

The CNP model considers the following elements: participants, communication needs processor, profile of needs, meaning processor, the language skills selector, the linguistic encoder, and the communicative competence specification.

Besides, the CNP includes eight parameters which give a description of specific communication needs. The parameters include purpose domain, setting, interaction, instrumentality, dialect, communicative event, communicative key, target level (for a detailed discussion of the parameter, see Munby, 1978).

The CNP has been criticized by many researchers. Flowerdew and Peacock (2001), for example, claimed the CNP model to be simplistic which merely generated a simple idea about learners' needs. These models did not characterize needs of all stockholders (i.e. teachers) and only identify some of learners' biographical information. West (1994) mentions the shortcomings of CNP due to its complexity, learner-centeredness, constraints, and language, the teaching establishment, and the user - institution.

\section{Situation Analysis}

According to this approach the sources of information are the students. Dudley- 
Evans and John (1998, p.125) state that "PSA estimates strengths and weaknesses in language, skills, learning experiences." The background information and the level of education about the learners can provide us with information about their present abilities.

According to Dudley-Evans and John (1998), there are eight components of needs analysis which have been grouped into four areas including: (target situation analysis and objective needs analysis, linguistic analysis, discourse analysis, and genre analysis, subjective needs analysis, and present situation analysis.

\section{Roles of ESP Teachers}

The role of ESP teachers involves much more than teaching, because teaching ESP is more challenging and difficult than teaching General English. Dudley-Evans and John (1998) propose following five key roles of ESP teacher: teacher, course designer and material provider, collaborator, researcher and evaluator Firstly, the teaching of ESP becomes more targeted. The ESP teacher, for example, identify certain students' needs, design and develop the course/material accordingly, and then help students attain the material. The teacher's role, in this sense, is to create authentic, communicative environment in class in which students learn the content. Secondly, and in corollary to the first, the ESP teacher is not only a selector or adaptor of authentic materials but also a developer of their own materials. To devise the materials, the ESP teacher may survey the availability of the material, select units from the course book to adapt if required, and add a number of extra units. He/she can provide a whole set of material only where no suitable material is unavailable.
The teacher then becomes a material provider and designer of the course (Huq,2011, Dudley Evans\& John, 1998). Thirdly, ESP teachers might have to work with the cooperation of sponsors or subject specialists. ESP teachers have to anticipate potential problems and avoid them, while creating a harmonious working arrangement. The collaboration should be a two-way process. The subject teacher can assist to learn more about the learner's target situation; on the other hand, the ESP teacher can make the specialist aware of the language problems learners face (Huchinson and Waters, 2002). In addition, teachers should research the aim that they want to achieve. Then, they should design a course, arrange materials, and find out the particular interests of the students. At the same time, ESP teachers should research the content and context of the course to fulfill the needs of the students. Sometimes they are left with no options than to design and develop their own materials (Bracaj, 2014). Finally, General English courses are well-studied and improved by methodology specialists. On the other hand, an ESP course is unique; thus, it is not possible to design an ESP course to satisfy all ESP students. Therefore, ESP courses need continual evaluation in which teachers have to get involved. They have to evaluate the students' progress and teaching effectiveness. Additional evaluation of course and teaching materials are also crucial in ESP classes (Bracaj, 2014).

\section{Purpose of the Study}

As it is outlined above, both teachers and students face challenges in an ESP class. For this reason, the present research has been undertaken to support the teachers as a means to comprehend the needs and the challenges of an ESP class. The study is an 
attempt to find out the role of ESP teachers to facilitate learners to achieve their ESP needs. This is also an endeavor to identify some strategies to apply in an ESP class to make it more effective to motivate ESP learners.

\section{Methodology}

This is descriptive exploratory research that maintained survey method for data collection. The purpose of the study is to identify the purpose of Advanced English Language classes, the areas of language the students want to develop, and the types of logistic support and class the students want. The study also intends to investigate the role of the teachers, when students should enroll in the course, the type of material that the students think should be included in the course, and so on. For the primary data collection process, two separate sets of structured questionnaires were designed. The first set of questionnaire was designed for the students (see appendix A), and the second set of questionnaire was designed for the teachers (see appendix B).The sources of secondary data collection process were publications, research studies and journals. After analyzing the data the responses were counted, tallied and calculated into percentages.

For the questionnaire survey, 64 undergraduate students from the Department of Civil Engineering of Stamford University Bangladesh and East West University, and 20 teachers from the same universities have been selected. The experience of the teachers varies from 2 to 12 years. Among the participants, 10 are assistant professors, 6 are senior lecturers, and 4 are lecturers. The universities, teachers, and students were selected randomly for the survey.

\section{Data Collection Tools}

For collecting information, questionnaires were prepared for both the students and teachers. The questionnaires for the students contained 12 fixed alternative questions, and for the teachers 5 fixed questions with one open-ended question. In the open-ended question, the teachers were allowed to provide their comments and suggestions. After collecting the survey results, the responses were counted into percentage into two tables. In this research, opinions and feedbacks of the respondents were given priority.

\section{Findings}

\section{Responses from students}

This study aimed to evaluate the responses collected from the tertiary level students of the private universities. In the questionnaire (See Appendix B), the first question was about students' current level of proficiency in English. In reply, 46.875\% answered they have average level of proficiency level in English. From the reply of the second question, it has been found that $25 \%$ students preferred study, $12.5 \%$ students preferred research, $12.5 \%$ students preferred social purpose, and $25 \%$ students preferred profession, whereas $25 \%$ students preferred study abroad option as the immediate purpose to learn Technical Writing and Communication course. The third question was about when the students use English. In reply, 53.123\% students answered they use English when studying. Similarly, the next question asked about the areas the students wish to develop more. $37.5 \%$ students chose speaking, $3.125 \%$ students selected listening, $18.75 \%$ students selected to develop reading, $6.25 \%$ students preferred writing, $15.625 \%$ chose 
vocabulary, $6.25 \%$ students preferred grammar. In the next question, the students were asked if they knew the reason of doing Technical Writing and Communication course. In reply, 56.25\% students replied they want to develop professional communication in writing and speaking.

The reason of doing Technical Writing and Communication course

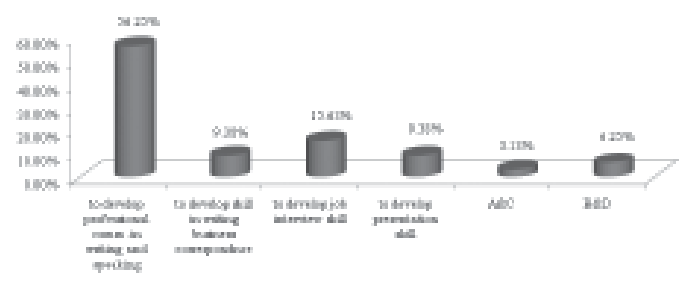

Figure 1. Reasons for an ESP course

Similarly, the next question asked was if they knew how the students want the instructional materials to be delivered. $43.75 \%$ students wanted the instructional materials to be delivered face to face, and $57.25 \%$ students wanted the instructional materials to be delivered through online and multimedia. In the seventh question, the students were inquired of the type of classroom they want for the Technical Writing and Communications course. In reply, $37.5 \%$ students preferred classroom with white-boards and OHP, $12 \%$ students wanted classroom multimedia facilitated with sound system, 25\% demanded internet and multimedia facilitated classroom with sound system, and $25 \%$ students desired internet and multimedia facilitated classroom with sound system and decorated with posters and maps. In the eighth question, the students were asked what kind of English class the students like. In reply, $87.5 \%$ students preferred class with lot of activities, pair/group work and projects. Then the participants were asked whether English courses should use materials more relevant to their major courses. In reply, 75\% students selected "Yes" option. The following question was about the role the students like teachers to play. $62.5 \%$ students answered teachers should play the role of facilitator and guide.

Next, the students were asked about the time of enrollment in this course. In reply, as the figure below illustrates, $62.55 \%$ students opined the course should be offered in the beginning of the program.

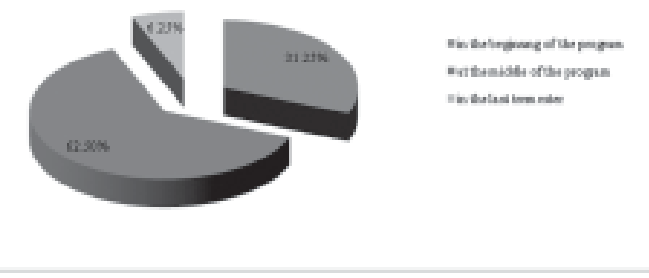

Figure 2. Students' want of time enrollment in ESP course

In the last question the students were enquired about the type of material they think the course should include. $12.5 \%$ students think the course should include textbooks, instruction/equipment manuals, CDs, DVDs, videotapes, 25\% students think that the course should include materials used on a job, such as work forms, charts and samples of relevant course assignment and relevant papers, $31.25 \%$ students opined the course should include materials from websites like business letters, emails, resume, memos, press releases, dialogues, telephone conversations, and so on, and $31.25 \%$ students selected combination of all options.

\section{Responses from teachers}

After collecting data from the teachers' questionnaire (See Appendix C), it has been 
found that, $100 \%$ teachers considered Advanced Reading Strategies and Writing/ Technical Writing and Communication course to be designed to cater the vocational needs of the students. Similarly, $80 \%$ teachers wanted the instructional materials to be delivered through on line and multimedia. etc.

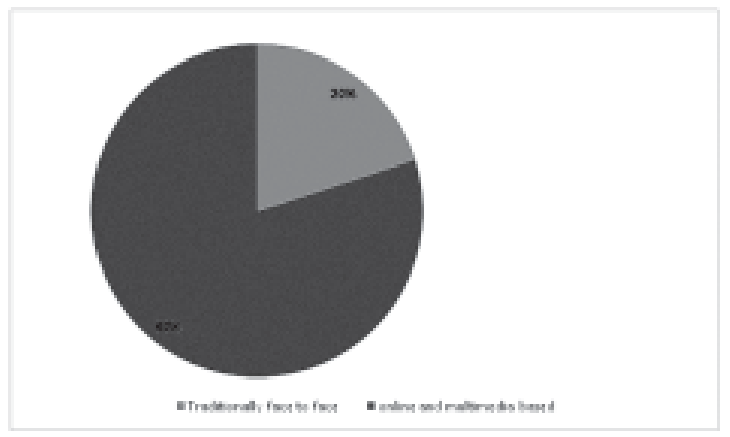

Figure 3. How the instructional materials should be delivered

In addition, most of the $(80 \%)$ teachers wanted classroom to be equipped with internet, and multimedia with adequate sound system. Agreeing with students, 60\% teachers want the students should enroll at the middle of the program. The survey also found that, $80 \%$ teachers thought the course should include materials used on a job, such as work forms, charts and samples of relevant course assignment and relevant papers, and the course should incorporate materials from websites like business letters, emails, resume, memos, press releases, dialogues, telephone conversations,

\section{Recommendations}

On the basis of the analysed data and the findings, and the open-ended question set for the teachers, the following suggestions can be recommended. The implementation of these recommendations may help to bring about some positive changes in teaching English for Specific Purpose at tertiary level.

1. Needs analysis of the students should be done at the beginning of the course to develop the curriculum content, teaching materials, and methods, and to bridge up the gap between classroom material and requirements of the workplace.

2. ESP learners do not require all topics of General English, instead they should be taught limited and specific topics according to their professional needs. To bridge the gap between what is written in the textbook and what is needed in the workplace, the educators should cover the specific academic and occupational areas, so the learners can face the real world when they enter the job market.

3. Teachers have to know the specific purpose of the learners that they use in professional life, and have to simulate those activities in the classroom.

4. The students of the particular department can be supplied materials according to the professional needs of their own fields.

5. Teachers can adapt ideas about those professionals and organize the materials accordingly. For example, the students of Pharmacy and Business may attend the same course but with different materials. The teacher may get a clear idea what type of communication bankers, pharmacists, multi-national executives need in their profession.

6. The course can be helpful for the students if it is designed according to 
the needs, level and objectives to the students.

7. Instructors should have professional job experience or training to provide maximum output. The concerned universities should take responsibilities to offer ESP training for existing and future teachers.

8. At the tertiary level, students are well aware of grammar rules and errors; they can learn easily with classroom activities by using real-life communication.

9. Instead of enrolling in the beginning or at the end of the program, students should enroll in ESP courses at the middle of the program.

\section{Limitations of the Study}

Although the objective of the study was well defined, some limitations need to be mentioned for future improvement. Only private universities have been selected for data collection. Inclusion of public universities might present a different scenario all together. Monetary and time constraint acted as a barrier to conduct the research in a large scale. The research was conducted on a small group of students (64) and teachers (20). Study was conducted only in the capital city of Dhaka; universities situated in other large cities could be included for more applicable generalization. The research of limited context can act as a sample parameter to carry out future research of a larger scale.

\section{Conclusion}

The article is an attempt to provide an overview of ESP, its characterizing features, needs analysis and the roles of ESP teachers. The role of an ESP teacher is more complex and difficult than a General English teacher. Teachers should be given some special training according to the vocational needs of students. The syllabus should be properly designed and material should be appropriately developed to cater all the components of the future workplace of the learners. Furthermore, rather than being a traditional teacher, an ESP instructor should play the role of a guide and facilitator to get learners involved.

\section{References}

Bracaz, M. MSC. (2014). Teaching English for Specific Purposes and Teacher Training. European Scientific Journal. 10(2), 40-49.

Burton, M. (2009). An account of ESP-with possible feature directions. English for Specific Purpose. 3(24), 8-18. (retrieved from http:/ / www.esp-world.info).

Coffey, B. (1984). State of the art article English for Specific Purposes. Language Teaching. 17(1), 2-16.

Dudly-Evans, T. \& St. John, M. (1998). Developments in English for Specific Purposes. Cambridge: Cambridge University Press.

Flowerdew, J. \& Peacock, M. (2001). Issues in EAP. A Preliminary Perspective. Cambridge: Cambridge University Press.

Harding, K. English for Specific Purposes. (2012). Oxford: Oxford University Press.

Huq, S, ATM. (2011). Opportunities and Challenges in Teaching ESP in Private Universities in Bangladesh. Crossings: 
Ulab Journal of English Studies.3(1), 259-272.

Huchinson, T., \& Waters, A. (2002). English for Specific Purposes: A learner-centered approach. Cambridge: Cambridge University Press.

Long, M. (2005). Second language needs analysis. Cambridge, Cambridge University Press.

Lorenzo, F. (2005). Teaching English for specific purposes. UsingEnglish.com. Retreived March 2, 2014 from http:/ / www.usingenglish.com/teachers / articles/teaching-english-for-specificpurposes-esp.html.

Munby, J. (1978). Communicative Syllabus Design. Cambridge: Cambridge University Press.

Songhori, H. M. (2008). Introduction to Needs Analysis. English for Specific Purpose world.4, 1-25.

West, R. (1994). Needs Analysis in language teaching. Language teaching, 27(1),119.

\section{Appendix A: Designing a Course Outline to teach Technical Writing and Communication for Civil Engineering}

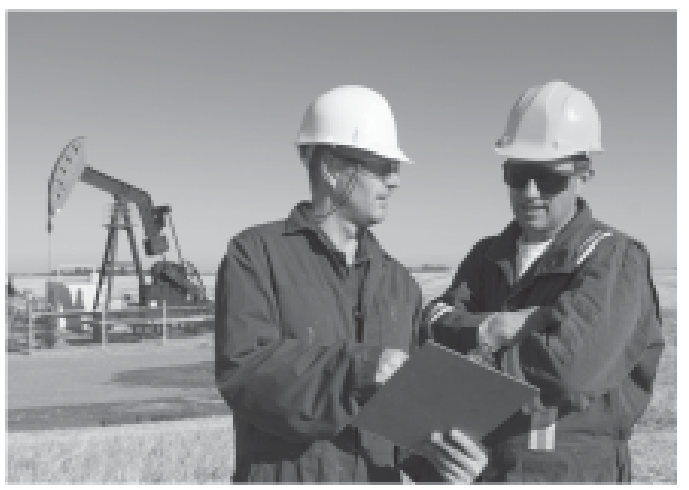

\section{Aims and Objectives}

This course is primarily designed to provide the opportunity for understanding and improving communication skills: specially reading and writing

- to become an informed reader and critic of any text written in English

- to gain an understanding of the underlying principles of effective writing styles
- to gain understanding of the importance of the organization techniques of writing adapting to a variety of audiences and occasions

- to demonstrate an ability to prepare and deliver effective written responses

- to improve skills in critical reading and thinking.

\section{Syllabus}

- Writing notes

- Writing messages (condolence, thanks, and congratulations)

- Writing E-mail

- Writing Memo

- Press Release

- Writing advertisement \& notices

- Graph Analysis

- $\quad$ Business Letter (Claim, Adjustment) 
- $\quad$ CV \& Cover Letter

- Learning technical vocabulary

- Editing/Correction

- Reading Comprehension

\section{Materials}

Required Textbook:

1. Heffernan, James A.W, John. E. Lincoln and Janet Atwill, Writing - A College Handbook, W.W.Norton \& Company

2. How to Write First-class Business Correspondence. L. Sue Bough. NTC Publishing

3. Langan, John, English Skills, 7th edition, McGraw-Hill Publications.

\section{Course Assessment}

- Class Work

- Home Work

- Group Activity

- Class Test

- Peer Evaluation

- Reports

- Library Research

- Written and Verbal discussions with supervisor/instructor

- Assignments etc.

\section{Grade Scale}

\begin{tabular}{|c|c|c|c|}
\hline Marks |X| & $\begin{array}{l}\text { Letter } \\
\text { Criade }\end{array}$ & $\cos$ & husurnent \\
\hline $80-100$ & At & 4.09 & Outstandine \\
\hline $75-79$ & A & 1.75 & Pacelert \\
\hline 7D-J4 & A. & 150 & Very Cosd \\
\hline 65.69 & 8* & 3.25 & Good \\
\hline $60-64$ & 8 & 3.00 & Above Average \\
\hline 55.59 & n- & 2.75 & Average \\
\hline 50.54 & c* & 2.50 & Below Average \\
\hline 45.49 & $\mathrm{C}$ & 2.5 & Peer \\
\hline $40-44$ & D & 200 & Pass \\
\hline co-19 & $\boldsymbol{F}$ & $0 \mathrm{~m}$ & Fall \\
\hline
\end{tabular}

\section{Target Situation Analysis}

Moving ahead from the basic reading and writing techniques introduced in COMPOSITION course, a more critical, thorough, creative and analytical responses are sought in Technical Writing and Communication. This course is designed to cultivate an understanding of the psychological, social, political and practical significance of communication in English with special emphasis on students' spontaneous judgment and articulation. 


\section{Appendix B: Survey Questionnaire for the Students and their responses:}

\section{Table-1: The MCQ questions asked to the students and their responses}

\begin{tabular}{|c|c|c|c|c|c|c|c|c|c|c|c|}
\hline \multirow{3}{*}{\begin{tabular}{|l|}
\multicolumn{1}{|c|}{ Question Topic } \\
$\begin{array}{l}\text { 1. What is the level of current } \\
\text { proficiency level in } \\
\text { English? }\end{array}$ \\
$\begin{array}{l}\text { 2. What is the immediate } \\
\text { purpose to learn Technical }\end{array}$ \\
$\begin{array}{l}\text { Writing and Communica- } \\
\text { tion course? }\end{array}$
\end{tabular}} & \multicolumn{11}{|c|}{ Responses } \\
\hline & $\begin{array}{l}\text { Excelleı } \\
3.125 \%\end{array}$ & \multicolumn{3}{|c|}{$\begin{array}{c}\text { Very } \\
\text { good6.25\% }\end{array}$} & $\begin{array}{c}\text { Good } \\
28.125 \%\end{array}$ & \multicolumn{4}{|c|}{$\begin{array}{l}\text { Average } \\
46.875 \%\end{array}$} & \multicolumn{2}{|c|}{ Poor 8.125\% } \\
\hline & $\begin{array}{l}\text { Study } \\
25 \%\end{array}$ & \multicolumn{3}{|c|}{$\begin{array}{c}\text { Research } \\
12.5 \%\end{array}$} & $\begin{array}{l}\text { Social } \\
\text { urpose } \\
.25 \%\end{array}$ & \multicolumn{2}{|c|}{$\begin{array}{l}\text { Trave } \\
16.25 \%\end{array}$} & \multicolumn{2}{|c|}{$\begin{array}{l}\text { Profession } \\
\quad 25 \%\end{array}$} & \multicolumn{2}{|c|}{ Study abroad 25\% } \\
\hline $\begin{array}{l}\text { 3. When do the students learn } \\
\text { English? }\end{array}$ & $\begin{array}{l}\text { Studying } \\
53.123 \%\end{array}$ & \multicolumn{2}{|c|}{$\begin{array}{l}\text { Socializing } \\
9.375 \%\end{array}$} & \begin{tabular}{l|c} 
ing & At h \\
$\%$ & 3.12
\end{tabular} & me & \multicolumn{2}{|c|}{$\begin{array}{l}\text { Others } \\
18.75 \%\end{array}$} & \multicolumn{2}{|c|}{$\begin{array}{c}\text { Studying anc } \\
\text { socializing } \\
6.25 \%\end{array}$} & \multicolumn{2}{|c|}{$\begin{array}{l}\text { Socializing and } \\
\text { at home } 9.375 \%\end{array}$} \\
\hline $\begin{array}{l}\text { 4. What are the areas of } \\
\text { language the students want } \\
\text { to develop? }\end{array}$ & $\begin{array}{c}\text { Speaking } \\
37.5 \%\end{array}$ & \multicolumn{2}{|c|}{$\begin{array}{l}\text { Listening } \\
3.125 \%\end{array}$} & $\begin{array}{l}\text { Reading } \\
18.75 \%\end{array}$ & $\begin{array}{l}\text { Writing } \\
6.25 \%\end{array}$ & \multicolumn{2}{|c|}{$\begin{array}{l}\text { Vocabulary } \\
15.625 \%\end{array}$} & \multicolumn{2}{|c|}{$\begin{array}{cc}\text { y } & \text { Grammar } \\
6 & 6.25 \%\end{array}$} & $\begin{array}{c}\text { Speaking } \\
\text { and reading } \\
3.125 \%\end{array}$ & $g \mid \begin{array}{c}\text { Speaking } \\
\text { and } \\
\text { vocabulary } \\
3.125 \%\end{array}$ \\
\hline $\begin{array}{l}\text { 5. What are the reason of } \\
\text { doing Technical Writing and } \\
\text { Communication course? }\end{array}$ & \multicolumn{2}{|c|}{\begin{tabular}{|c|} 
To develop \\
professional \\
communication \\
in writing and \\
speaking \\
$56.25 \%$ \\
\end{tabular}} & \multicolumn{2}{|c|}{\begin{tabular}{|c|} 
To develop \\
skill in \\
writing \\
business \\
comespondence \\
$9.375 \%$ \\
\end{tabular}} & \multicolumn{2}{|c|}{$\begin{array}{l}\text { To develop } \\
\text { job } \\
\text { interview } \\
\text { skill } \\
15.625 \%\end{array}$} & \multicolumn{3}{|c|}{$\begin{array}{c}\text { To develop } \\
\text { presentation } \\
\text { skill } \\
9.375 \%\end{array}$} & $\begin{array}{l}\text { A \& C } \\
3.125 \%\end{array}$ & $\begin{array}{l}\text { B \& D } \\
6.25 \%\end{array}$ \\
\hline $\begin{array}{l}\text { 6. How do the students want } \\
\text { the instructional materials to be } \\
\text { delivered? }\end{array}$ & \multicolumn{5}{|c|}{ Face to face $43.75 \%$} & \multicolumn{6}{|c|}{$\begin{array}{l}\text { On line and multimedia based } \\
57.25 \%\end{array}$} \\
\hline $\begin{array}{l}\text { 7. What type of classroom } \\
\text { the students want for the } \\
\text { Technical Writing and } \\
\text { Communications course? }\end{array}$ & \multicolumn{3}{|c|}{$\begin{array}{l}\text { Classroom with } \\
\text { white-board and } \\
\text { OHP37.5\% }\end{array}$} & \multicolumn{2}{|c|}{$\begin{array}{c}\text { Multimedia } \\
\text { facilitated with } \\
\text { sound } \\
\text { system } 12.5 \%\end{array}$} & \multicolumn{3}{|c|}{$\begin{array}{l}\text { Internet and } \\
\text { multimedia } \\
\text { facilitated with } \\
\text { und system } 25 \%\end{array}$} & \multicolumn{3}{|c|}{\begin{tabular}{|c} 
Internet and multimedia \\
facilitated with sound \\
system and decorated \\
with posters and maps \\
$25 \%$ \\
\end{tabular}} \\
\hline $\begin{array}{l}\text { 8. Kind of English class the } \\
\text { students like }\end{array}$ & \multicolumn{5}{|c|}{$\begin{array}{l}\text { Class with lot of activities, pair/ } \\
\text { group work and projects } 87.5 \%\end{array}$} & \multicolumn{6}{|c|}{$\begin{array}{l}\text { Teaching only by the teacher and no } \\
\text { activity by the students } 12.5 \%\end{array}$} \\
\hline $\begin{array}{l}\text { 9. Whether English courses } \\
\text { should use materials more } \\
\text { relevant to their major courses }\end{array}$ & \multicolumn{5}{|c|}{ Yes75\% } & \multicolumn{6}{|c|}{ No25\% } \\
\hline $\begin{array}{l}\text { 10. What kind of role the } \\
\text { students like teachers to } \\
\text { have? }\end{array}$ & \multicolumn{5}{|c|}{$\begin{array}{l}\text { Teacher as a facilitator and guide } \\
62.5 \%\end{array}$} & \multicolumn{6}{|c|}{$\begin{array}{l}\text { Traditional role of teacher who controls } \\
\text { everything in the class } 37.5 \%\end{array}$} \\
\hline $\begin{array}{l}\text { 11. Time of enrollment in this } \\
\text { course }\end{array}$ & \multicolumn{4}{|c|}{$\begin{array}{l}\text { In the beginning of the } \\
\text { program } 31.25 \%\end{array}$} & \multicolumn{4}{|c|}{$\begin{array}{l}\text { At the middle of the } \\
\text { program } 62.5 \%\end{array}$} & \multicolumn{3}{|c|}{$\begin{array}{l}\text { In the last } \\
\text { trimester } 6.25 \%\end{array}$} \\
\hline $\begin{array}{l}\text { 12. What type of material the } \\
\text { students think the course should } \\
\text { include? }\end{array}$ & $\begin{array}{r}\text { Textl } \\
\text { instruction } \\
\text { manuals, } \mathrm{C} \\
\text { videota }\end{array}$ & $\begin{array}{l}\text { books, } \\
\text { /Equip } \\
\text { CDs, D } \\
\text { pes12.5 }\end{array}$ & $\begin{array}{l}\text { DVDs, } \\
\text { b\% }\end{array}$ & $\begin{array}{r}\text { Material } \\
\text { such a } \\
\text { charts } \\
\text { rele } \\
\text { assignm } \\
\text { pa }\end{array}$ & $\begin{array}{l}\text { ls used o } \\
\text { as work f } \\
\text { and sam } \\
\text { evant cou } \\
\text { ent and l } \\
\text { apers25\% }\end{array}$ & $\begin{array}{l}\text { n a job, } \\
\text { orms, } \\
\text { ples of } \\
\text { irse } \\
\text { relevant } \\
\text { o }\end{array}$ & $\begin{array}{r}\text { Ma } \\
\text { li } \\
\text { em } \\
\text { pres } \\
\text { tele }\end{array}$ & $\begin{array}{l}\text { laterial } \\
\text { like bu } \\
\text { mails, r } \\
\text { ess rele } \\
\text { ephone } \\
\text { etc }\end{array}$ & $\begin{array}{l}\text { lines, } \\
\text { eesum } \\
\text { eases, } \\
\text { e con } \\
\text { c.31.2 }\end{array}$ & $\begin{array}{l}\text { n websites } \\
\text { s letters, } \\
\text { le, memos, } \\
\text { dialogues, } \\
\text { versations, } \\
5 \%\end{array}$ & $\begin{array}{l}\text { Combination } \\
\text { of all } \\
31.25 \%\end{array}$ \\
\hline
\end{tabular}




\section{Appendix C: Survey Questionnaire for the Teachers}

The following table shows the MCQ questions asked to the instructors and their responses:

\section{Table-2: The MCQ questions asked to the teachers and their responses}

\begin{tabular}{|c|c|c|c|c|c|c|}
\hline Question Topic & \multicolumn{6}{|c|}{ Responses } \\
\hline $\begin{array}{l}\text { 1.Should Advanced Reading } \\
\text { Strategies and Writing } \\
\text { Technical Writing and } \\
\text { Communication course be } \\
\text { designed to cater the vocational } \\
\text { needs of the students? }\end{array}$ & \multicolumn{3}{|c|}{ Yes $100 \%$} & \multicolumn{3}{|c|}{ No $0 \%$} \\
\hline $\begin{array}{l}\text { 2. How do the teachers want } \\
\text { the instructional materials to } \\
\text { be delivered? }\end{array}$ & \multicolumn{3}{|c|}{ Traditionally face to face $20 \%$} & \multicolumn{3}{|c|}{ On line and multimedia based $80 \%$} \\
\hline $\begin{array}{l}\text { 3. What type of classroom } \\
\text { teachers want for the } \\
\text { Advanced Reading Strategies } \\
\text { and Writing/Technical Writing } \\
\text { and Communication course? }\end{array}$ & $\begin{array}{c}\text { Classroom with } \\
\text { white-board and } \\
\text { OHP } 0 \%\end{array}$ & $\begin{array}{l}\text { Multimedia } \\
\text { facilitated } \\
\text { with sound } \\
\text { system } 0 \%\end{array}$ & $\begin{array}{r}\text { Inte } \\
\text { mu } \\
\text { facili } \\
\text { sour }\end{array}$ & $\begin{array}{l}\text { rnet and } \\
\text { ltimedia } \\
\text { tated with } \\
\text { d system } \\
80 \%\end{array}$ & \multicolumn{2}{|c|}{$\begin{array}{l}\text { Internet and multimedia } \\
\text { facilitated with sound } \\
\text { system and decorated with } \\
\text { posters and maps } 20 \%\end{array}$} \\
\hline $\begin{array}{l}\text { 4. When the students should } \\
\text { enroll in the course? }\end{array}$ & $\begin{array}{l}\text { In the beginning o } \\
\text { the program } 20 \%\end{array}$ & \multicolumn{3}{|c|}{$\begin{array}{l}\text { At the middle of the } \\
\text { program } 60 \%\end{array}$} & \multicolumn{2}{|c|}{ In the last trimester $20 \%$} \\
\hline $\begin{array}{l}\text { 5. What type of Material the } \\
\text { teachers think the course } \\
\text { should include? }\end{array}$ & $\begin{array}{l}\text { Textbooks, } \\
\text { instruction/ } \\
\text { Equipment } \\
\text { manuals, CDs, } \\
\text { DVDs, videotapes } \\
0 \%\end{array}$ & $\begin{array}{r}\text { Materials us } \\
\text { job, such as } \\
\text { forms, char } \\
\text { samples of } \mathrm{r} \\
\text { course assig } \\
\text { and relevant } \\
10 \%\end{array}$ & $\begin{array}{l}\text { d on a } \\
\text { work } \\
\text { s and } \\
\text { levant } \\
\text { iment } \\
\text { papers }\end{array}$ & $\begin{array}{r}\text { Mate } \\
\text { websites } \\
\text { letters, er } \\
\text { men } \\
\text { release } \\
\text { tel } \\
\text { conv } \\
\text { et }\end{array}$ & $\begin{array}{l}\text { ials from } \\
\text { ike business } \\
\text { ails, resume, } \\
\text { ss, press } \\
\text { dialogues, } \\
\text { phone } \\
\text { rsations, } \\
.10 \%\end{array}$ & $\begin{array}{l}\text { Combination } \\
\text { of all } 80 \%\end{array}$ \\
\hline
\end{tabular}

\section{Contributor}

Sharmin Siddique is an Assistant Professor in the department of English at Stamford University Bangladesh. She obtained B.A. (Hon's) and M.A. (Literature) from National University. She also completed M.A. (ELT) from Presidency University. At present she is pursuing M.Phil. at Bangladesh University of Professionals. Her areas of interest include ELT Management, Language Skills, Syllabus Design and Material Development. 